\title{
TULU $\bar{U}^{\prime} A L-H I L \bar{A} L$ \\ Rekonstruksi Konsep Dasar Hilāa
}

\author{
Nur Aris \\ STAIN Kudus \\ e-mail: nur_aris_75@yahoo.com
}

\begin{abstract}
This paper intends to review the basic concepts of crescent issue as the most fundamental concepts of the Hijri calendar systems. The crescent basic concept of tulü al-hiläl, based on these principles: first, put the crescent as a matter of objective existence does not depend on the subject or observer, but the object itself. Second, the lower moon extremity as a conceptual reference for basic concepts. Third, the beginning of the lunar calender is based on crescent moon rising. This paper also tries to determine the cause of the beginning of lunar calender with the normative traditions of the prophet to analyze the visual sighting of the crescent and istikmāl from the philosophy of Islamic Law's point of view. Normative cause of fasting Ramadan is not obligatory visual sighting of the crescent of Ramadan, but the rising of the crescent (tulü' al-hilăl). Visual sighting of the crescent and istikmāl and also Astronomy is a way to find out and make sure that the cause has occurred and they are not the cause by itself.
\end{abstract}

Tulisan ini bermaksud untuk menelaah kembali konsep-konsep dasar dari isu sabit sebagai konsep yang paling mendasar dari sistem kalender Hijriah. Konsep dasar țulü' alhilāl yaitu: pertama, menempatkan bulan sabit sebagai hal yang objektif yang keberadaannya tidak tergantung pada subjek atau pengamat, tapi pada objek itu sendiri. Kedua, ekstrimitas bawah bulan menjadi acuan konseptual sebagai konsep dasar. Ketiga, awal bulan lunar didasarkan pada terbitnya bulan sabit. Tulisan ini juga mencoba menentukan penyebab normatif awal bulan lunar dengan menganalisis tradisi nabi terhadap penampakan visual dari sabit dan istikmāl dari sudut pandang Filsafat Hukum Islam. Penyebab normatif puasa wajib Ramadhan bukanlah penampakan visual dari bulan sabit, melainkan naiknya bulan sabit (tưlü' al-hilāl). Penampakan visual dari sabit dan istikmāl dan juga Astronomi adalah cara untuk mengetahui dan memastikan bahwa penyebab normatif telah terjadi namun mereka bukan penyebab normatif itu sendiri.

Keywords: sebab normatif, sabit naik (țulū'al-hilāl), konjungsi, struktur logis, hilāl

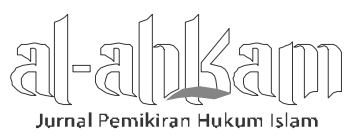


Nur Aris

\section{Pendahuluan}

Hilāl adalah salah satu fenomena astronomis yang sangat penting kedudukannya dalam sistem penanggalan Hijriyah. Hal ini didukung oleh al-Qur'an alKarim:

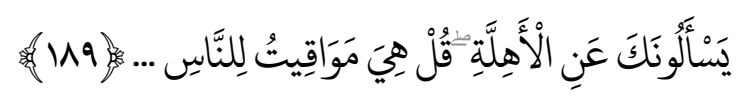

"Mereka bertanya kepadamu tentang hilāl-hilāl, katakanlah Muhammad! Hilāl adalah penentu waktu bagi manusia dan ibadah Haji."1

Al-ahillah (bentuk plural dari hilāl) dalam ayat tersebut diposisikan oleh alQur'an sebagai penentu waktu (time keeping) bagi umat manusia. Penyebutan al-nās (manusia) pada ayat di atas menunjukkan bahwa penggunaan fenomena hilāl sebagai penentu waktu tidak hanya digunakan oleh umat Islam saja tetapi juga umat yang lainnya. Sedangkan penyebutan penentu waktu haji menunjukkan bahwa ibadah haji lebih banyak terkait dengan hilāl dari pada fenomena astronomis lainnya. Kapan pelaksanaan wukuf, kapan berhari raya Idul Adha, semua itu terkait langsung dengan hilāl. Pengkhususan ibadah haji dalam ayat tersebut juga mengindikasikan perlunya kesatuan penanggalan untuk seluruh umat Islam.

Kajian-kajian tentang penanggalan Hijriyah tidak akan lepas dari pembahasan terhadap konsep dasar hilāl. Konsep dasar hilāl menempati posisi yang sangat strategis dalam sistem penanggalan Hijriyah. Hal ini karena untuk menentukan awal masuknya bulan baru (new month) dalam sistem penanggalan Hijriyah tergantung pada hilāl ini. Bahkan kajian-kajian dalam ilmu hisab pada dasarnya adalah usaha untuk menentukan posisi hilāl saat akhir bulan Qamariyah untuk menentukan awal bulan Qamariyah yang baru.

Melihat betapa strategisnya posisi hilāl dalam sistem penanggalan Hijriyah, maka pembahasan tentang konsep dasar hilāl perlu dilakukan untuk memahami jenis dan struktur logisnya. Di Indonesia saat ini, paling tidak terdapat tiga konsep dasar hilāl yang digunakan dalam tiga tradisi yang berbeda, yaitu tradisi fikih konvensional, tradisi observational astronomy dan tradisi wujūd al- hilāl. Tulisan ini menganalisis konsep dasar hilāl dalam tiga tradisi tersebut dari aspek struktur logis konseptualnya. Dengan pembahasan ini diharapkan diketahui perbedaan konsep dasar hilāl yang ada untuk kemudian merumuskan kembali konsep dasar

${ }^{1}$ QS. al-Baqarah: 189.

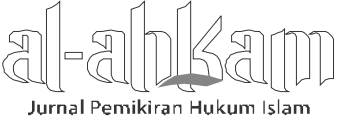


hilāl yang struktur logisnya lebih adequate ${ }^{2}$ atau yang sebaiknya digunakan sebagai dasar penentuan awal bulan Qamariyah.

\section{Konsep Dasar Hilāl dalam Tiga Tradisi}

\section{Konsep Dasar Hiläl dalam Tradisi Fikih Konvensional}

Hilāl yang bentuk jama'nya al-ahillah adalah ghurrat al-qamar, yaitu bentuk bulan paling awal ketika terlihat pertama kali oleh manusia pada awal bulan. ${ }^{3}$ Ada yang mengatakan bahwa hilāl adalah bentuk bulan untuk dua malam pertama dari suatu bulan Qamariyah, dan selanjutnya tidak disebut hilāl sampai bulan berikutnya. Namun, ada yang mengatakan hilāl adalah bentuk bulan pada tiga malam pertama dari suatu bulan Qamariyah, setelah itu disebut dengan al-qamar ${ }^{4}$.

Secara etimologi kata hilāl berasa dari kata halla-yuhillu-ihlālan. Ahalla-yuhilluihlālan artinya melihat hilāl. Makna asal dari ihlal adalah rafu al-saut yaitu mengeraskan suara. Orang yang mengeraskan suaranya sering disebut dengan muhillun. Ahalla bi 'l-hajj artinya orang yang berhaji mengeraskan suaranya ketika membaca talbiyah. Istahalla al-șabiyyu șarihan, artinya seorang bayi menagis keras ketika dilahirkan. Dan bentuk bulan pertama disebut dengan hiläl karena kebiasaan orang memekikkan suaranya ketika melihatnya, seraya bertakbir dan berdoa. ${ }^{5}$

Dalam Mu'jam Lughah al-Fuqahā' disebutkan bahwa kata istihlāl bentukan dari kata hilāl dalam sya'ir Arab berarti bait paling awal. Istihlāl al-maulūd artinya adalah bersuara keras. Apa saja yang istahalla artinya adalah bersuara keras. Dan hilāl disebut dengan hilāl karena orang berteriak keras ketika melihatnya. ${ }^{6}$ Hilāl adalah bentuk mașdar dari halla. Jamaknya adalah ahillah atau ahālil, yaitu bulan pada awal bulan Qamariyah sampai hari ke-7, dan dari hari ke-27 sampai akhir bulan. ${ }^{7}$

\footnotetext{
${ }^{2}$ Adequate secara bahasa bisa diartikan dengan memadai dan dalam tradisi filsafat sering diartikan dengan sifat kebenaran yang dihasilkan dari kognisi tingkat kedua yang kebenarannya tidak tergantung pada faktor eksternal atau dari luar dirinya, tetapi cukup dari dirinya sendiri.

${ }^{3}$ Muhạammad ibnu Makrūm ibn Manẓūr, Lisān al-'Arab (Beirut: Dar Sadir, t.th.), h. 707.

${ }^{4}$ Ibid., h. 701.

${ }^{5}$ Abū al-Ḥusain Ahmad ibn Faris, Maqāyis al-Lughah, Juz 6 (tt.tp: Ittihād al-Kitābal-'Arab, 2002), h. 11.

6Muhammad Rowas Qa'lahj̄̄, Mu'jam Lughāt al-Fuqahā’ (Beirut: Dār an-Nafāis, 1988), h. 72.

${ }^{7}$ Ibid., h. 106.$$
\square
$$

Jurnal Pemikiran Hukum Islam 
Di dalam kitab Aisār al-Tafāsir li Kalām al-'Aliyy al-Kabīr juga disebutkan bahwa hilāl adalah bentuk bulan pada awal kemunculannya di tiga malam pertama karena orang ketika melihatanya akan berteriak "al-hilāl! al-hilāl!"8 Demikian pula pendapat al-Baghdādy dalam kitabnya Tafsīr al-Khāzin'. Ibn 'Ashūr dalam kitabnya al-Tahrīr wa '-Tanwīr menambahkan, bahwa hilāl adalah bulan pada awal pertemuan dengan matahari pada malam pertama dan kedua. ${ }^{10}$ Menurut al-Samin al-Halabiy dalam kitabnya al-Durr al-Masūn fi 'Ilm al-Kitāb al-Maknūn, hilāl adalah benda langit yang sudah dikenal dan sudah menjadi nama untuk benda langit tersebut.11

Konsep dasar hilāl di dalam tradisi fikih konvensional termasuk jenis konsep yang pure-empiris, karena ia dihubungkan dengan empiris atas dasar observasi. Ketika konsep hilāl dikaitkan dengan "bersuara keras (berteriak)" saat terlihat secara empiris dalam bentuk sabit, artinya hilāl disebut ada secara empiris, dan hilāl disebut tidak ada ketika tidak terlihat secara empiris. Dengan demikian, dalam sudut pandang fikih keberadaan hilāl tidak tergantung kepada posisi tertentu dari bulan, bumi dan matahari, tidak tergantung pada standar illuminasi tertentu, pada sudut elongasi tertentu, tidak tergantung pada umur tertentu atau parameter-parameter lainnya. Dengan kata lain, konsep hilāl dalam tradisi fikih konvensional bersifat pureempiric sensual (inderawi/ teramati).

Kesimpulan ini juga didukung dengan wacana di dalam tradisi fikih tentang terlihatnya hilāl pada siang hari. Sebagaimana pembahasan yang dilakukan oleh Ibn 'Ābidīn'12 dalam kitabnya Hāshiyah Radd al-Mukhtār 'alā ad-Durr al-Mukhtār Sharh Tanwīr al-Abșār Fiqh Abū Hanīfah. Al-Qarāfì dalam kitabnya adh-Dhākirah bahkan menyebutkan ada sekelompok orang yang melihat hilāl pada siang hari.13 Jauh sebelum para ahli fikih di atas, Imam Mālik dalam al-Mudawwanah al-Kubrā juga menyinggung terlihatya hilāl pada siang hari.14

\footnotetext{
${ }^{8}$ Abū Bakar Aisār Al-Jazā'irī, al-Tafāsir li Kalām al-'Alìy al-Kabīr, Juz 1 (t.t.p.: 2003), h. 170.

9'Alauddin 'Aliy ibnu Muḥammad al-Khāzin, Tafsir al-Khazin al-Lubāb at-Ta'wīl fi Ma'āniy at-Tanzīl (ttp, 1979,) h. 66.

10Muhammad al-Tāhir ibn 'Așur, al-Tahrīr wa '-Tanwīr, Juz 1 (t.t.p.: Dār al-Tunisiyyah li al-Nassr, 1997), h. 192.

11al-Samīn al-Halabī, al-Dur al-Masūn fi 'Ilm al-Kitāb al-Maknūn, Juz 1 (t.t.p.: t.th.), h. 705.

${ }^{12}$ Hāshiyah Radd ibn 'Ābidīn, al-Mukhtar alā al-Durr al-Mukhtār Sharh Tanwīr al-Abṣar Fiqh Abū Haniffah, juz 2 (t.t.p.: 2000), h. 392-393.

13Ṣihabuddin Ahmad ibnu Idris Al-Qarafī, al-Dhakhirah, juz 2 (Beirut: Dār al-Gharb, 1994), h. 424.

14Ibn Anas ibnu Mālik, al-Mudawwanah al-Kubrā, juz 1 (Beirut: Dār al-Kutub al-'Ilmiyyah, T.th), h. 267.
}

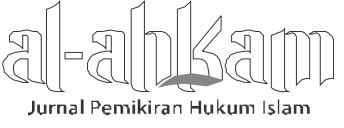


Konsep dasar hilāl dalam tradisi fikih konvensional yang demikian ini, berimplikasi pada masuknya tanggal 1 bulan baru didasarkan pada hilāl empiris sensual, yaitu hilāl yang betul-betul telah berhasil diobservasi dengan mata. Konsep hilāl demikian banyak dianut oleh ahli fikih sejak masa Islam awal bahkan sampai sekarang ini. Konsep hilāl yang empiris sensual ini membawa kepada pemahaman jika hilāl tidak dapat diobservasi pada tanggal 29 bulan Qamariyah berjalan, meskipun secara Astronomys sudah sangat mungkin terobservasi, maka bulan berjalan digenapkan 30 hari. Konsep yang demikian itu bisa juga membawa kepada pemahaman untuk melakukan rukyah pada tanggal 29 meskipun hilāl terbenam terlebih dahulu dari pada matahari.

Sebagai contoh adalah pengumuman Majlis al-Qaḍā' al-A'lā Saudi Arabia yang menghimbau umat Islam untuk melakukan observasi terhadap hilāl awal syawal 1433 H. Keadaan hilāl Syawal 1433 pada koordinat Mekah saat matahari terbenam pada tanggal 29 Ramadhan 1433 (Jum'at, 17 Agustus 2012) tidak terlihat oleh masyarakat yang melakukan rukyah di Saudi Arabia, sehingga bulan Ramadhan digenapkan menjadi 30 hari, sehingga 1 Syawal 1433 H (Idul Fitri) jatuh pada tanggal 19 Agustus 2012 sebagaimana keputusan Majlis Qaḍa $\bar{a}^{\prime}$ al-A'lā tentang awal Syawal 1433 H.15

Pengumuman tersebut semakin menegaskan bahwa konsep hilāl dalam tradisi fikih konvensional adalah konsep yang pure empiris. Hal tersebut berimplikasi pada perintah untuk rukyah yang dilaksanakan pada 17 Agustus 2012, meskipun secara astronomis hilāl pada tanggal 17 Agustus 2012 saat matahari terbenam tidak mungkin terlihat atau malah belum terbentuk karena belum terjadi konjungsi. Hisab astronomis modern memastikan bahwa pada saat magrib di Mekah, belum terjadi konjungsi. Konjungsi terjadi pada pukul 18:55, matahari terbenam di Mekah pada pukul 18:49:52 dan bulan terbenam pada pukul 18:29:59.16

Struktur logis hilāl yang pure empiris di atas, dalam tradisi fikih konvensional masih harus didukung dengan variable normatif yang dikenal dengan istilah shahādah. Selama klaim rukyah didukung dengan shahādah (kesaksian) maka klaim itu diterima. Dalam tradisi fikih, shahādah memegang peran yang sangat

\footnotetext{
15http://www.fatwa-online.com/news/0120817.htm diakses pada tanggal 2013.

16Khafid, Software Mawaqit.

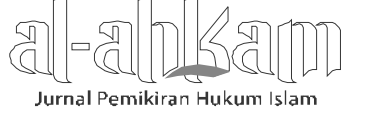

Jurnal Pemikiran Hukum Islam 
Nur Aris

penting dalam konsep hilāl. Tanpa shahādah maka klaim rukyah terhadap kenampakan hilāl ditolak. Dengan demikian konsep hilāl dalam tradisi fikih adalah konsep empiris -normatif.

\section{Konsep Dasar Hilāl dalam Tradisi Observational Astronomy}

Berbeda dengan konsep hilāl dalam tradisi fikih, hilāl dalam tradisi astronomi didefinisikan sebagai fenomena penampakan bulan yang dilihat dari bumi setelah ijtimak atau konjungsi. Sebagaimana definisi hilāl yang disampaikan oleh EG Richards dalam bukunya Mapping Time: the Calendar and Its History bahwa hilāl adalah The crescent moon as it first appears after a conjunction. ${ }^{17}$

Hilāl dalam bahasa Inggris disebut dengan crescent. Crescent adalah bagian bulan yang bercahaya yang tampak dari permukaan bumi yang merupakan fase antara new moon dan first quarter. Pada fase new moon sisi gelap bulan menghadap ke bumi, sedangkan sisi terangnya mengahadap ke arah matahari, fase ini terjadi pada saat konjungsi. ${ }^{18}$

Dalam Oxford Dictionary of Astronomy disebutkan bahwa hilāl adalah salah satu fase bulan, ketika illuminasinya kurang dari setengah sebagaimana yang tampak oleh pengamat.19 Dalam Philip's Astronomy Encyclopedia disebutkan bahwa hilāl adalah fase bulan antara new moon (bulan baru) dan first quarter (kuartal pertama), atau antara fase kuartal terakhir dengan fase new moon. Hilāl juga disebut fase sebuah planet inferior antara konjungsi inferior dengan 'elongasi' terbesar, ketika sisi illuminasinya yang kurang dari setengah tampak. ${ }^{20}$

Dari uraian tentang konsep hilāl dalam astronomi di atas, dapat disimpulkan bahwa hilāl dalam tradisi asronomi adalah salah satu fase bulan yang berbentuk bulan sabit yang terlihat secara empiris di sekitar ufuk barat saat matahari terbenam yang sebelumnya didahului dengan konjungsi. Definisi ini memasukkan variabel konjungsi sebelum hilāl terlihat. Sedangkan syarat terjadinya konjungsi

\footnotetext{
${ }^{17}$ Richards, E.G., Mapping Time: the Calendar and Its History (New York: Oxford University Press, 1998), h. 407.

18Forest Ray Moulton, An Introduction to Astronomy (New York: The Mac Millan Company, 1916), h. 191.

${ }^{19}$ Ian Ridpath, Oxford Dictionary of Astronomy (New York: Oxford University Press, 1997), h. 109.

${ }^{20}$ Sir Patrick Moore (eds), Philip's Astronomy Encyclopedia (London: Philip's Group, 2002), h. 106.
}

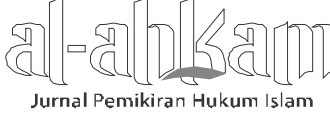


tidak pernah disebut-sebut dalam tradisi fikih konvensional. Dengan demikian, hilāl akhir Ramadhan $1433 \mathrm{H}$ pada sore hari tanggal 17 Agustus 2012 dalam perspektif astronomi belum terbentuk. Tetapi, dalam perspektif fikih mungkin saja hilāl sudah ada karena terlihat, meskipun belum konjungsi karena Ramadhan sudah tanggal 29, sebagaimana himbauan Majlis Qaḍā' al-A'lā kepada seluruh masyarakat Saudi untuk melihat-lihat hilāl pada 29 Ramadhan $1433 \mathrm{H}$.

Dengan demikian, konsep hilāl dalam tradisi Observational Astronomy adalah hilāl empiris-logis dengan parameter sudah terjadi konjungsi sebelum hilāl tersebut terlihat. Namun di sisi lain ada sebagian astronom yang mencoba menteorikan visibilitas hilāl. Teori ini mencoba menjelaskan parameter-parameter yang memberikan pengaruh terhadap keterlihatan hilāl. Misalnya adalah parameter Babilonia yakni time lag antara moonset dan sunset dan umur bulan seperti orang Babilonia. ${ }^{21}$ Kemudian ada juga parameter kombinasi antara umur, altitude dan elongasi seperti yang ditawarkan MABIMS22 dan lain-lain.

Dari uraian di atas, dapat disimpulkan bahwa konsep hilāl dalam tradisi Observational Astronomy bersifat empiris-logis-verifikatif. Dikatakan empiris karena konsep hilāl didasarkan pada observasi jangka panjang untuk mengetahui universalitas keterlihatan hilāl. Dikatakan logis karena pertama, apabila ada laporan hilāl teramati dengan posisi hilāl tidak sesuai dengan parameter yang telah dirumuskan, maka hilāl yang terlihat tersebut dianggap bukan hilāl, tetapi mungkin benda langit lainnya atau kesalahan lihat. Kedua, apabila di suatu waktu, hilāl dengan posisi sudah sesuai atau bahkan di atas parameter yang telah ditetapkan oleh teori visibilitas hilāl, tetapi ketika observasi hilāl tidak terlihat secara empiris, maka hilāl secara teoritis sudah dianggap ada. Konsep dasar hilāl seperti di atas juga menempatkan hilāl sebagai objek yang keberadaannya tergantung pada subjek. Ia disebut hilāl apa tidak tergantung pada terlihatnya hilāl tersebut oleh pengamat atau tidak.

Berikut ini adalah gambar ilustrasi konsep hilāl dalam tradisi Observational Astronomy:

\footnotetext{
21 Muhammad Ilyas, Astronomy of Islamic Calendar (Kuala Lumpur: AS Noordeen, 1997), h. 77.

${ }^{22}$ Lihat: Keputusan Lokakarya "Mencari Format Kriteria Awal Bulan Hijriyah di Indonesia 2011" yang diadakan di Hotel Ussu Bogor pada tanggal 19-21 September 2011.
}

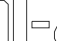

Jurnal Pemikiran Hukum Islam 


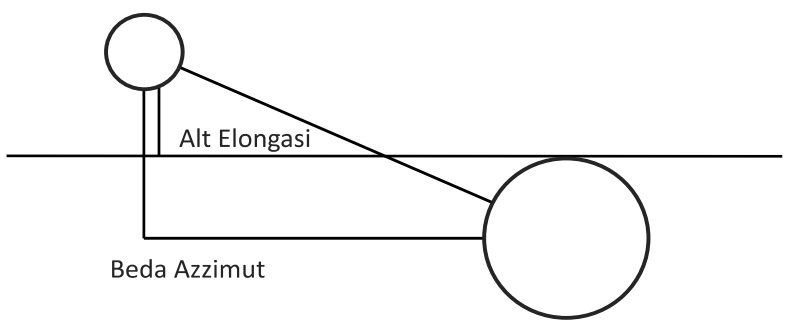

\section{Gambar 1. \\ Konsep Hilāl dalam Tradisi Observational Astronomy}

\section{Konsep Dasar Hilāl dalam Tradisi Wujūd al-Hilāl}

Konsep dasar hilāl dalam tradisi wujūd al-hilāl Muhammadiyah berbeda struktur logisnya dengan struktur logis dua konsep hilāl sebelumnya. Wujūd alhilāl berasal dari dua kata, yaitu wujūd dan al-hilāl. Wujud berasal dari kata wajada, yajidu, wujūdan. Wajada berarti ada atau mengada dengan sendirinya. ${ }^{23}$ Dengan demkian, wujūd al-hilāl secara bahasa berarti mengadanya hilāl atau adanya hilāl.

Hilāl dalam wujūd al-hilāl bukanlah konsep yang pure empiris-normatif sebagaimana halnya konsep hilāl dalam tradisi fikih dan bukan pula konsep hilāl empiris-logis-verifikatif dalam tradisi observational astronomy. Hilāl dalam wujūd al-hilāl adalah konsep logis-'hepotetico'-matematis. Ia tidak dirumuskan berdasar pada empiri dengan melalui observasi tetapi melalui penalaran rasional-teoritik.

Konsep hilāl dalam tradisi wujūd al-hilāl, tidak harus teramati secara empiris oleh pengamat dari permukaan bumi. Konsep dasar hilāl yang digunakan mengacu kepada tiga parameter teoritik astronomi yang bersifat kumulatif (ketiga parameter harus terpenuhi) sebagai referensinya. Ketiga parameter tersebut adalah: 1) Telah terjadi ijtimā', 2) Ijtimā' terjadi sebelum matahari terbenam, 3) Pada saat matahari terbenam bulan (piringan atasnya) masih di atas ufuk.24

Konsep hilāl dengan parameter teoritik di atas menjadikan konsep hilāl dalam tradisi wujūd al-hilāl terlepas dari aspek empiris sebagaimana konsep hilāl dalam

\footnotetext{
23Ibn Manẓūr, Lisān al-'Arab, Juz 3, h. 445

24Tim Majelis Tarjih dan Tajdid PP Muhammdiyah, Pedoman Hisab Muhammadiyah (Yogyakarta: Majelis Tarjih dan Tajdid Muhammadiyah, 2009), h. 23.
}

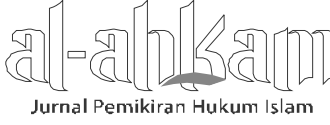


dua tradisi sebelumnya. Dengan demikian, keberadaan hilāl dalam wujūd al-hilāl tidak bisa dibuktikan secara empiris. Keberadaan hilāl dalam tradisi wujūd al-hilāl hanya bisa dibuktikan secara logis-hepotetis. Usaha apapun untuk menguji secara empiris eksistensi hilāl dalam konsep wujūd al-hilāl ini adalah perbuatan yang sia-sia.

Pembuktian keberadaan hilāl dalam tradisi wujūd al-hilāl hanya bisa dilakukan secara logis-hepotetis. Salah satu pengujian logis yang bisa ditempuh misalnya adalah dimulai dengan aksioma atau postulat yang menyatakan bahwa sesaat setelah terjadi konjungsi, maka iluminasi bulan akan betambah besar dan nilainya pasti akan lebih dari 0\%. Ketika matahari terbenam dan beberapa saat sebelumnya telah terjadi konjungsi maka hakikatnya ada wajah bulan yang bercahaya (iluminated) meskipun sangat kecil. Tabel berikut ini berisi data konjungsi dan illuminasi bulan ketika matahari terbenam untuk tiap awal bulan tahun $1433 \mathrm{H}$. Data-data konjungsi dan iluminasi dihitung dengan Software Mawaqit 2001.

Tabel 1.

Data Konjungsi dan Illuminasi Bulan Setiap Bulan Tahun 1433 H (Mawāqīt 2001) dengan Marja' Pati

\begin{tabular}{|c|c|c|}
\hline No. & Bulan & Data Bulan dan Matahari \\
\hline 1 & Muharram & $\begin{array}{l}\text { Konjungsi }=25 \text { Nopember } 2011 \text { Pukul 13:10 } \\
\text { Matahari terbenam }=17: 36: 48 \\
\text { Bulan terbenam }=17: 44: 02 \\
\text { Illuminasi }=0.71 \% \text {, Alt: } 1^{\circ} 7^{\prime} 41,6^{\prime \prime}\end{array}$ \\
\hline 2 & Safar & $\begin{array}{l}\text { Konjungsi }=25 \text { Desember } 2011 \text { Pukul 01:07 } \\
\text { Matahari terbenam }=17: 51: 40 \\
\text { Bulan terbenam }=18: 25: 51 \\
\text { Illuminasi }=0.69 \% \text {, Alt: } 6^{\circ} 57^{\prime} 54,3^{\prime \prime}\end{array}$ \\
\hline 3 & Rabiul Awal & $\begin{array}{l}\text { Konjungsi = } 23 \text { Januari 2012 Pukul 14:40 } \\
\text { Matahari terbenam = 18:01:32 } \\
\text { Bulan terbenam = 17:57:52 } \\
\text { Illuminasi = 0.15\%, Alt: - 0 55’ 52,8” (Hilāl belum } \\
\text { wujud karena parameter ke-3 tidak terpenuhi) }\end{array}$ \\
\hline 4 & Rabius Tsani & $\begin{array}{l}\text { Konjungsi }=22 \text { Pebruari } 2012 \text { Pukul 05:35 } \\
\text { Matahari terbenam = 17:57:58 } \\
\text { Bulan terbenam }=18: 06: 03 \\
\text { Illuminasi }=0.47 \% \text {, Alt: } 1^{\circ} 27^{\prime} 36,9^{\prime \prime}\end{array}$ \\
\hline
\end{tabular}


Nur Aris

$5 \quad$ Jumadil Awal

6 Jumadil Akhir

$7 \quad$ Rajab

8 Sya'ban

9 Ramadhan

10 Syawal

11 Zulkaidah

12 Zulhijah
Konjungsi $=25$ Maret 2012 Pukul 21:37

Matahari terbenam $=17: 44: 58$

Bulan terbenam $=17: 25: 13$

Illuminasi $=0.19 \%$, Alt: $-5^{\circ} 33^{\prime} 26,7^{\prime \prime}$ (Hilāl belum wujud karena ketiga parameter tidak terpenuhi)

Konjungsi = 21 April 2012 Pukul 14:18

Matahari terbenam $=17: 31: 17$

Bulan terbenam $=17: 27: 36$

Illuminasi $=0.07 \%$, Alt: $-0^{\circ} 55^{\prime} 43,8^{\prime \prime}$ (Hilāl belum wujud karena parameter ke-3 tidak terpenuhi)

Konjungsi = 21 Mei 2012 Pukul 06:47

Matahari terbenam $=17: 25: 13$

Bulan terbenam $=17: 41: 22$

Illuminasi $=0.18 \%$, Alt: 3 1' 20,1"

Konjungsi = 19 Juni 2012 Pukul 22:02

Matahari Terbenam $=17: 28: 11$

Bulan terbenam $=17: 15: 45$

Illuminasi $=0.06 \%$, Alt: $-3^{\circ} 34^{\prime} 44,5^{\prime \prime}$ (Hilāl belum wujud karena ketiga parameter tidak terpenuhi)

Konjungsi = 19 Juli 2012 Pukul 11:24

Matahari Terbenam $=17: 34: 30$

Bulan terbenam $=17: 42: 21$

Illuminasi $=0.21 \%$, Alt: $1^{\circ}$ 20’ $6,7^{\prime \prime}$

Konjungsi = 17 Agustus 2012 Pukul 22:55

Matahari Terbenam $=17: 36: 35$

Bulan terbenam $=17: 16: 24$

Illuminasi $=0.25 \%$, Alt: $-5^{\circ} 35^{\prime} 4,9^{\prime \prime}$ (Hilāl belum wujud karena ketiga parameter tidak terenuhi)

Konjungsi = 16 September 2012 Pukul 09:11

Matahari Terbenam $=17: 33: 18$

Bulan terbenam $=17: 41: 53$

Illuminasi $=0.31 \%$, Alt: $1^{\circ} 32^{\prime} 25,7^{\prime \prime}$

Konjungsi = 15 Oktober 2012 Pukul 19:03

Matahari Terbenam $=17: 29: 45$

Bulan terbenam $=17: 18: 06$

Illuminasi $=0.07 \%$, Alt: $-3^{\circ} 33^{\prime} 16,4^{\prime \prime}$ (Hilāl belum wujud karena ketiga parameter tidak terpenuhi).

Awal puasa $1433 \mathrm{H}$ menurut konsep dasar hilāl wujūd al-hilāl bertepatan dengan hari Jum'at tanggal 20 Juli 2012, karena meskipun ketinggiannya baru $1^{\circ}$ 
20 '6,7" tetapi hilāl sudah wujud dengan illuminasi 0.21\%. Berdasarkan postulat di atas, bahwa sekecil apapun illuminasi bulan pasca konjungsi sebelum maghrib maka sesunguhnya hilāl sudah terbentuk, karena pasti ada cahaya matahari yang terpantulkan dari bulan ke bumi, hanya saja cahaya iluminasi bulan tidak dapat dilihat secara empiris oleh pengamat di atas permukaan bumi. Berikut ini adalah gambar ilustrasi konsep dasar hilāl dalam tradisi wujūd al-hilāl:

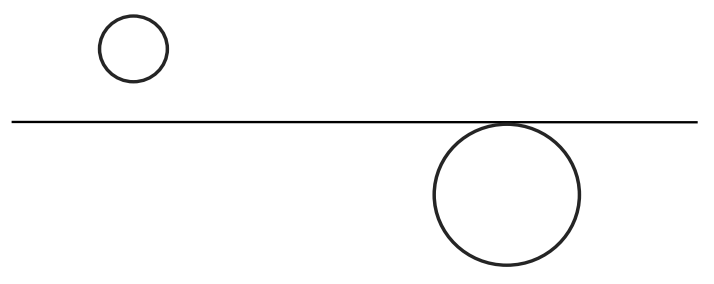

Gambar 2.

Konsep Dasar Hilāl dalam Tradisi Wujūd al-Hilāa

\section{Ṭulū'al-Hilāl sebagai Sebab Syar'i Awal Bulan Qamariyah}

Perbedaan konsep dasar hilāl dalam tiga tradisi di atas disebabkan oleh posisi filosofis yang berbeda. Posisi filosofis fikih konvensional adalah mempercayai sepenuhnya apa yang diinformasikan oleh naș dan apa yang dipraktekkan Rasulullah SAW. Dalam tradisi fikih konvensional, konsep (pengetahuan) yang benar dan valid adalah bersumber dari teks-teks keagamaan yang normatif, bukan rasio dan bukan empiri. Dengan demikian konsep hilāl dalam tradisi fikih konvensional juga bersifat normatif, sesuai dengan norma-norma yang ada di dalam naș. Ketika naș hanya menyebutkan satu saksi yang adil sudah cukup untuk membuktikan keberadaan hilāl, maka tidak perlu parameter-parameter lainnya. Ketika naș tidak mensyaratkan pembuktian, hanya mencukupkan kesaksian (shahadah) seorang yang dikenal adil, maka keberadaan hilāl cukup dengan kesaksian, tidak diperlukan bukti-bukti empiris apalagi citra hilāl (positivistisme logis) untuk menerima kesaksian tersebut.

Sedangkan posisi filosofis observational astronomy adalah bahwa pengetahuan yang valid yang benar adalah logis-empiris-verifikatif. Logis artinya sesuai dengan prinsip-prinsip umum logika ilmiah. Empiris artinya konsep hilāl didasarkan pada pengamatan empiris dan verifikatif artinya harus bisa diuji validitasnya di lapangan apakah sesuai dengan teori visibilitas hilāl dan ada tidaknya bukti empiris yang mendukung. Dengan demikian, apabila ada laporan bahwa hilāl terlihat tetapi tidak 
sesuai dengan teori visibilitas hilāl, maka tidak bisa diterima kecuali adanya cukup bukti-bukti empiris positivistik, misalnya adanya foto atau citra dan lain sebagainya.

Adapun posisi filosofis wujūd al-hilāl mencukupkan diri pada posisi logishepotetis (rasionalisme). Posisi filosofis ini beranggapan bahwa logika manusia sudah cukup untuk memperoleh pengetahuan yang valid. Dengan demikian, hilāl dalam posisi filosofis ini cukup bisa diketahui keberadaannya hanya dengan berpikir logika-matematis berdasar pada postulat (teori yang sudah dianggap benar), misalnya dengan cara menghitung iluminasi bulan pasca konjungsi, posisi hilāl, waktu moonset dan sunset. Kalau postulat itu benar, maka kesimpulan logikanya pasti benar. Sekecil apapun pencahayaan bulan pasca konjungsi, maka sesunguhnya ada bagian kecil permukaan bulan yang memantulkan cahaya matahari ke bumi. Ini artinya adalah bahwa hilāl sudah terbentuk. Dengan pemahaman logika hepotitico-matematis seperti ini, keberadaan hilāl dalam wujūd al-hilāl bisa dipahami dengan baik.

Berikut ini tabel perbedaan konsep dasar hilāl di antara tradisi fikih konvensional, tradisi observational astronomy dan tradisi wujūd al-hilāl.

Table 2.

Perbedaan Sifat Konsep Dasar Hilāl dalam

Tradisi Fikih Konvensional, Observational Astronomy dan Wujūdal-Hilāl

\begin{tabular}{|c|l|l|}
\hline No. & \multicolumn{1}{|c|}{ Tradisi } & \multicolumn{1}{c|}{ SifatKonsep Dasar Hiläl } \\
\hline 1 & Fikih & Empiris-normatif \\
\hline 2 & Observasional Astronomy & Empiris-logis-verifikatif \\
\hline 3 & Wujūd al-hilāl & Logis-hepotetis \\
\hline
\end{tabular}

Lalu, konsep dasar hilāl yang mana yang cukup adequate untuk dijadikan sebagai parameter masuknya awal bulan Qamariyah? Untuk menjawab pertanyaan di atas, langkah pertama yang harus dilakukan adalah menjawab pertanyaan dasar normatif berikut ini. Apakah terlihatnya hilāl di atas ufuq merupakan sebab syar'i masuknya awal bulan Qamariyah ataukah hanya cara untuk mengetahui sebab syar'i tersebut? Untuk menjawab pertanyaan ini ada dua hal yang harus dilakukan. Pertama, memahami kembali redaksi Hadis-Hadis yang memerintahkan untuk rukyah dan kedua adalah memahami sebab syar'i itu sendiri.

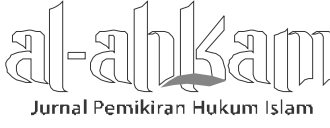


Salah satu Hadis yang menginformasikan perintah rukyah dan istikmāl untuk mengawali puasa Ramadhan adalah sebagai berikut ini:

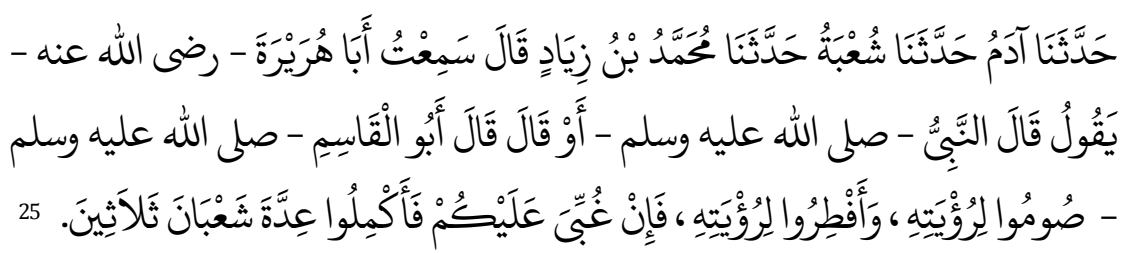

Hadis tersebut memerintahkan umat Islam untuk melakukan puasa apabila hilāl awal Ramadhan terlihat dan berbuka (beridul fitri) ketika hilāl awal bulan Syawal terlihat. Jika hilāl ghubbiya (tersembunyi) atau dalam redaksi lain ghummiya (jika mendung) sehingga hilāl tidak terlihat, maka umat Islam diperintahkan untuk menggenapkan jumlah hari bulan Sya'ban menjadi 30 hari.

Dalam Hadis tersebut tampak ada alternatif selain terlihatnya hilāl yaitu istikmāl. Apabila demikian, maka bisa dipastikan bahwa terlihatnya hiläl bukan menjadi sebab syar'i wajibnya puasa Ramadhan atau menjadi sebab syar'i untuk berbuka (beridul fitri). Karena suatu sebab tidak bisa digantikan dengan sebab lain dalam satu kasus. Hal ini sebagaimana yang disampaikan oleh al-Shātibi bahwa sesuatu yang sudah ditetapkan oleh syara' sebagai sebuah sebab dari sesuatu maka ia akan menjadi sebab dari sesuatu itu selamanya. Inilah yang dimaksud dengan sebab syar'i ${ }^{26}$

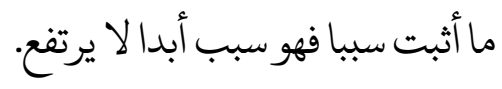

Untuk lebih memahami tentang konsep sebab syar'i ini misalnya adalah sebab syar'i wajibnya imsak (tidak makan dan minum) pada Puasa Ramadhan adalah terbitnya fajar șadiq. Ini berarti bahwa imsak diwajibkan atas umat Islam apabila fajar șadiq telah terbit, sehingga selama fajar șadiq belum terbit maka imsak dalam puasa Ramadhan tidak diwajibkan.

Lalu bagaimana cara untuk mengetahui bahwa fajar șadiq telah terbit? Al-Qur'an al-Karim hanya menjelaskan prinsip umum untuk mengetahui bahwa fajar telah terbit, yaitu dengan memerintahkan umat Islam untuk tabayun (to ensure, to get certainty) sebagaimana redaksi surat al-Baqarah ayat 187:

\footnotetext{
${ }_{25}$ Variasi redaksi hadith bisa dilihat pada Sahị̄h Bukhāri, Juz 7, h. 191; Sahīh Muslim, Juz 7, h. 32- 39; Musnād Ahmad, Juz 11, h. 416; Muwatța', Juz 2, h. 337 dan Sunān al-Nasa'i, Juz 7, h. 317-319. 109.

26Ibrahim ibn Mūsā ibn Muḥammad al-Shațibī, al- Muwāfaqāt, juz 1 (t.t.p.: Dār Ibn 'Affan, 1997), h.
}

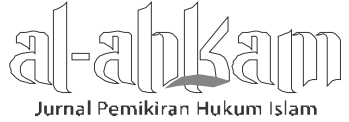


Nur Aris

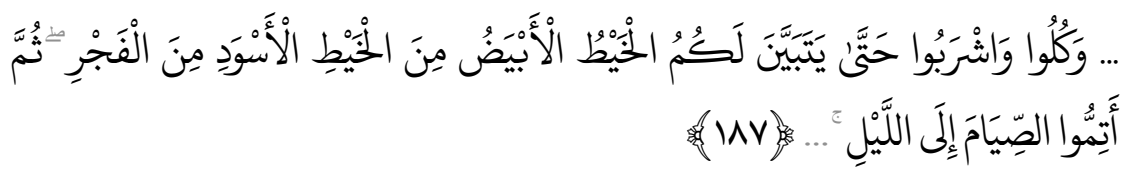

"... dan makan minumlah hingga terang bagimu benang putih dari benang hitam, yaitu fajar. kemudian sempurnakanlah puasa itu sampai (datang) malam."27

Ayat di atas hanya menjelaskan prinsip umum bahwa wajibnya imsak disebabkan oleh keyakinan dan kepastian bahwa fajar șadiq telah terbit. Kemudian bagaimana cara untuk mendapatkan keyakinan bahwa fajar șadiq telah terbit? Apa yang dipraktekkan oleh Bilāl ibn Rabbah seoarang muadzin pada masa Rasulullah menjelaskan cara tersebut. Dalam riwayat disebutkan bahwa Bilāl ibn Rabbah selalu melihat ke ufuk timur menjelang subuh. Observasi fajar șadiq selalu dilakukan oleh Bilal, dan ketika Bilāl melihat fajar șadiq telah terbit maka ia segera mengatakannya kepada Ummi Maktūm untuk mengumandangkan adzan subuh sebagai tanda waktu imsak telah datang.

Dari ilustrasi kasus imsak tersebut dapat dikatakan bahwa sebab syar'i tidak bisa dihilangkan dan diganti dengan sebab syar'i yang lainnya. Dengan demikian terlihatnya hilāl dan istikmāl bukanlah sebab syar'i wajibnya puasa Ramadhan dan wajibnya berbuka (beridul fitri) sebagaimana yang umumnya dipahami dari Hadis di atas. Pemahaman yang lebih mendekati kebenaran dari aspek ușūl al-fiqh adalah bahwa terlihatnya hilāl dan istikmāl adalah cara untuk mengetahui sebab syar'i bukan sebab syar'i itu sendiri.

Kalau terlihatnya hilāl bukan sebagai sebab syar'i wajibnya puasa Ramadhan, lalu apa yang menjadi sebab syar'i-nya? Al-Qur'an al-Karim menjelaskan sebab syar'i wajibnya puasa Ramadhan adalah shuhud (mengetahui) datangnya bulan Ramadhan. ${ }^{28}$ Surat al-Baqarah:185 menyebutkan:

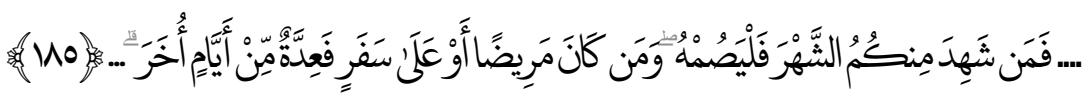

"... barang siapa di antara kamu hadir (di negeri tempat tinggalnya) di bulan itu, Maka hendaklah ia berpuasa pada bulan itu, dan barang siapa sakit atau dalam

\footnotetext{
${ }^{27}$ QS. al-Baqarah: 187.

${ }^{28}$ Abū Zakariyya Yahyyā ibn Sharāf al-Nawāwī, al-Majmū' Sharh al-Muhadhdhab (Kairo: Dār Ihyyā' at-Turāth al-'Arabī, 1422).
}

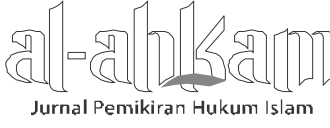


perjalanan (lalu ia berbuka), maka (wajiblah baginya berpuasa), sebanyak hari yang ditinggalkannya itu, pada hari-hari yang lain...." 29

Kata shahida dalam Bahasa Arab menurut Ibn Faris tidak bisa dimaknai kecuali dengan tiga pengertian, yaitu al-ḥuḍūr (hadir), al-ílmu (mengetahui) dan al-i'lām (informasi). ${ }^{30}$ Dia mengatakan:

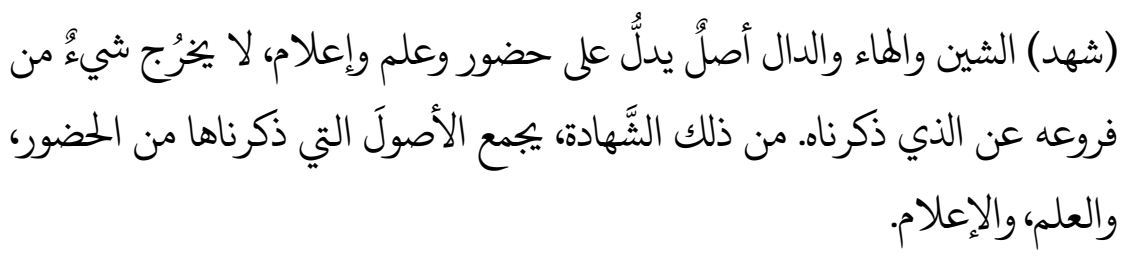

Dengan demikian, dapat disimpulkan bahwa yang menjadi sebab syar'i wajibnya puasa adalah datangnya bulan Ramadhan bukan terlihatnyta hilāl Ramadhan. Terlihatnya hilāl Ramadhan adalah cara untuk shahādah (mengetahui) datangnya bulan Ramadhan tersebut. Dengan kata lain ru'yat al-hiläl adalah cara (wasilah) dan tujuannya (ghāyah) adalah kepastian datangnya bulan Ramadhan. Demikian juga istikmāl ketika hilāl tidak terlihat merupkan cara (wasilah) untuk mencapai tujuan (ghāyah) tersebut. ${ }^{31}$

Apabila alur pikir di atas dapat diterima, maka selanjutnya rukyat al-hilāl (visibilitas hilāl) dan istikmāl tidak diposisikan sebagai sebab syar'i datangnya bulan Ramadhan. Dengan demikian tidak lain dan tidak bukan yang menjadi sebab syar'i datangnya bulan Ramadhan adalah țulü' al-hilāl (terbitnya hilāl) bulan Ramadhan. Pada masa Rasulullah dan para sahabat cara yang paling memugkinkan saat itu untuk mengetahui dengan pasti terbitnya hiläl Ramadhan adalah dengan rukyah dan istikmāl. Cara tersebut juga yang paling mudah untuk memastikan bahwa hilāl Ramadhan telah terbit. Apabila ada cara lain untuk mengetahui terbitnya hiläl yang lebih meyakinkan dan lebih adequate daripada terlihatnya hilāl dan istikmāl, maka bisa digantikan dengan cara yang lain tersebut. Hal ini sama dengan kasus terbitnya fajar șadiq sebagai sebab syar'i wajibnya imsak, di mana pada masa Rasulullah dan sahabat hanya bisa diketahui dengan observasi

\footnotetext{
${ }^{29}$ QS. al-Baqarah: 185.

30Maqāyis al-Lughāh Ibn Faris, Ittihād al-Kitāb al-'Arab (t.t.p.: 2002), h. 172.

${ }^{31}$ Ahmmad Muhammad Shakir, Awā'il al-Shuhur al-'Arabiyyah Hal Yajūzu Shar'an Ițbātuha bi 'lHisāb al-Falakiy (Kairo: Makabah Ibn Taimiyah, 1407).
}

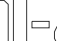

Jurnal Pemikiran Hukum Islam 
fajar șadiq (cahaya putih membentang di ufuk timur). Namun ketika ilmu hisab astronomys mampu untuk menentukan parameter terbitnya fajar șadiq, maka astronomi segera menggantikan observasi fajar șadiq sebagai cara untuk mengetahui terbitnya fajar. Sekarang ini tidak ada satu pun umat Islam yang keberatan untuk menggantikan observasi fajar șadiq dengan ilmu astronomi.

Dengan demikian, sesungguhnya tidak ada hubungan normatif-ahistoris antara terlihatnya hilāl dengan wajibnya puasa Ramadhan dan masuknya awal bulan Qamariyah lainnya. Hubungan yang ada adalah hubungan teknis-historis antara terlihatnya hilāl dengan wajibnya Puasa Ramadhan dan awal bulan Qamariyah lainnya. Hubungan yang demikian menjadikan terlihatnya hilāl dan istikmāl bersifat meruang waktu, yang berarti ia bisa saja berubah seiring dengan perubahan ruang dan waktu. Sedangkan hubungan terbitnya hilāl Ramadhan dengan wajibnya Puasa Ramadhan memiliki hubungan yang bersifat normatif-ahistoris, yang berarti sampai kapanpun, di manapun terbitnya hilāl Ramadhan akan selalu menjadi sebab syar'i wajibnya puasa Ramadhan, dan tidak akan bisa berubah selamanya. Jenis hubungan ini dapat dilihat pada tabel berikut:

Table 3.

Jenis Hubungan Konsep Visibilitas Hiläl, Istikmāl, Ilmu Hisab dan Ṭulü'al-Hilāl dengan Wajibnya Puasa Ramadhan

\begin{tabular}{|c|c|}
\hline Konsep & $\begin{array}{l}\text { Pola Hubungan dengan Wajibnya } \\
\text { Puasa Ramadhan }\end{array}$ \\
\hline Terlihatnya Hilāl (visibilitas hilāl) & Teknis-Historis (meruang waktu, singular) = cara \\
\hline Istikmāl & Teknis-Historis (meruang waktu, singular) = cara \\
\hline Ilmu Hisab & Teknis-Historis (meruang waktu, singular) = cara \\
\hline Terbitnya Hilāl & $\begin{array}{l}\text { Normatif-ahistoris (tidak meruang waktu, universal) = } \\
\text { sebab syar'i }\end{array}$ \\
\hline
\end{tabular}

Melihat pola hubungan sebagaimana tabel di atas, dapat disimpulkan juga bahwa kedudukan terlihatnya hilāl, istikmāl dan ilmu hisab adalah sama yaitu sebagai cara teknis untuk memperoleh kepastian apakah hilāl Ramadhan telah terbit atau belum. Oleh karena itu, ilmu hisab hanya digunakan untuk mendapatkan kepastian apakah hilāl Ramadhan telah terbit atau belum, bukan untuk mengetahui keterlihatan hilāl, karena posisi terlihatnya hilāl dan ilmu hisab adalah sama-sama sebagai cara untuk mencapai kepastian tersebut. 
Pola hubungan keempat konsep dalam tabel di atas dapat dilihat pada gambar berikut ini:

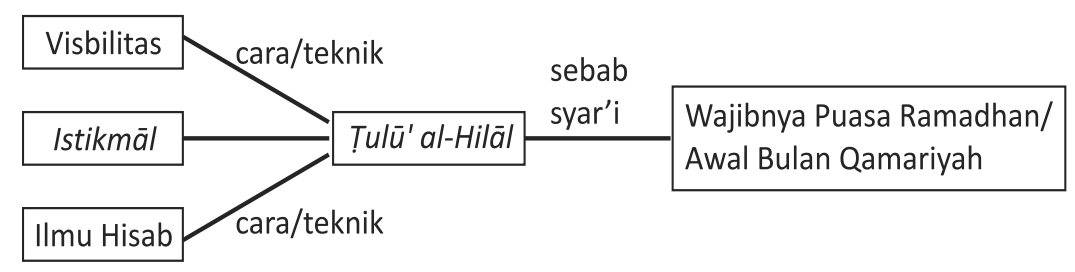

\section{Gambar 3. \\ Pola Hubungan Konsep Visibilitas Hilāl, Istikmāl, Ilmu Hisab dan Wajibnya Puasa Ramadhan}

Konsep hilāl dalam tradisi fikih konvensional yang pure empiris-normatif apabila digunakan sebagai parameter terbitnya hilāl bisa menyebabkan memulai awal bulan Qamariyah lebih cepat atau lambat. Misalnya, adalah kasus mengawali awal Ramadhan di Saudi Arabia yang beberapa kali bermasalah dari sudut pandang ilmiyah karena hilāl terbenam lebih dahulu dari pada matahari atau bahkan belum terjadi konjungsi. Sedangkan konsep hilāl dalam tradisi observational astronomy bisa menyebabkan keterlambatan dalam mengawali bulan Qamariyah, apabila parameter visibilitas hilāl yang digunakan sangat tinggi. Meskipun demikian, konsep dasar hilāl dalam tradisi observational astronomy memiliki kelebihan tersendiri yaitu diperolehnya kepastian bahwa hilāl telah wujud dan bahwa hilāl telah terbit.

Adapun konsep hilāl dalam tradisi wujūd al-hilāl, yaitu terbenamnya bulan setelah terbenamnya matahari yang sebelumnya didahului dengan konjungsi masih menyisakan persoalan dari sisi struktur logis hilāl itu sendiri. Dengan masuknya variable terbenamnya bulan setelah terbenamnya matahari, membawa konsekuensi pada parameter piringan atas bulan yang menjadi acuannya. Parameter yang demikian kadang menjadikan hilāl yang sesungguhnya belum terbit tapi sudah masuk awal bulan Qamariyah. Hal ini dikarenakan struktur logis konsep dasar hilāl mestinya mengacu kepada parameter piringan bawah bulan, bukan piringan atas bulan. Ketika posisi matahari lebih rendah dari bulan maka tentu bagian yang bercahaya tidak mungkin bagian piringan atas bulan, tetapi bagian bawahnya atau bagian bulan yang menghadap ke arah matahari. Konsep dasar hilāl dalalm tradisi wujūd al-hilāl memang dapat memastikan bahwa hilāl 
Nur Aris

telah wujud, tetapi hilāl dalam tradisi ini sesungguhnya belum tentu dipastikan telah terbit. Hal ini karena ketika matahari terbenam piringan bawah bulan sebagai representasi bentuk hilāl masih di bawah ufuk.

Dari analisis terhadap konsep dasar hilāl dalam tiga tradisi di atas, menurut hemat penulis, ketiganya kurang adequate untuk dijadikan referensi dalam penentuan awal bulan Qamariyah. Oleh karena perlu dilakukan rekonseptualisai terhadap hilāl yang lebih adequate. Konsep hilāl yang adequate menurut hemat penulis adalah țulü' al-hiläl. Parameter yang digunakan untuk mengukur țulü' alhilāl agar konsep hilāl adequate dalam penentuan awal bulan Qamariyah adalah apabila piringan bawah bulan sudah di atas ufuq ketika matahari terbenam.

Dengan demikian parameter țulū'al-hilāl sebagai sebab syar'i masuknya awal bulan Qamariyah adalah apabila memenuhi dua parameter astronomis secara kumulatif berikut ini:

1. Sudah terjadi konjungsi sebelum matahari terbenam.

2. Piringan bawah bulan sudah ada di atas ufuq (positif) saat matahari terbenam atau lebih dari $0^{\circ}$.

Berikut ini adalah gambar ilustrasi konsep dasar hilāl dalam țulū' al-hilāl pada kondisi hilāl minimum.

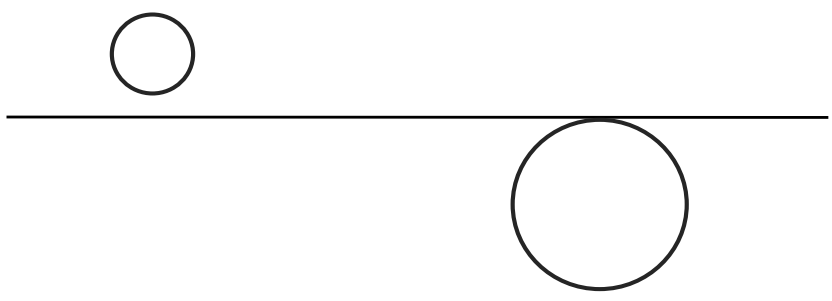

Gambar 4.

Konsep Dasar Hilāl dalam Ṭulü'al-Hilāl

\section{Kesimpulan}

Dari pembahasan di atas dapat disimpulkan:

Pertama, sebab syar'i masuknya awal bulan qamariyah adalah țulü al-hilāl, bukan wujūd al-hilāl dan bukan pula terlihatnya hilāl (visibilitas hilāl). Konsep hilāl 
dalam tradisi fikih, Observational astronomy dan tradisi wujūd al-hilāl tidak cukup adequate untuk dijadikan sebagai referensi dalam penentuan awal bulan Qamariyah.

Kedua, konsep țulū' al-hilāl yang mengacu kepada dua parameter yaitu piringan bawah bulan sudah di atas ufuk saat matahari terbenam dan telah tejadi konjungsi sebelumnya adalah konsep yang tepat sebagai referensi dalam penetuan awal bulan Qamariyah.[a]

\section{DAFTAR PUSTAKA}

'Ābidīn, Hāāshiyah Radd Ibn, al-Mukhtār 'ala 'l-Durr al-Mukhtār Sharh Tanwīr alAbṣār Fiqh Abū Hanīfah, juz 2, t.t.p.: 2000.

Ahmad, Ibn Ḥanbal, Musnad Aḥmad, t.t.p.: Mawqi' Wizārāt al-Auqāf al-Miṣriyah, t.th.

'Așur, Muhammad al-Tāhir Ibn, al-Tahrīr wa 'l-Tanwīr, Juz 1, t.t.p.: Dār alTunīsiyyah li an-Nasr, 1997.

al-Bukharī, Muḥammad ibn Ismā'īl, al-Jāmī’ al-Ṣāḥihh, Beirut: Dār Ibn Kathīr, 1987.

Fāris, Abī al-Husayn Aḥmad Ibn, Maqāyis al-Lughah, Juz 6, t.t.p.: Ittihād al-Kitāb al'Arab, 2002.

al-Ḥalabī, As-Samīn, al-Dur al-Masūn fì 'Ilm al-Kitāb al-Maknūn, Juz 1, t.t.p.: t.th.

Ibn Manzūr, Muhammad ibnu Makrūm, Lisān al-'Arab, Beirut: Dār Sādir, t.th.

Ilyas, Muhammad, Astronomy of Islamic Calendar, Kuala Lumpur: AS Noordeen, 1997.

al-Jazā'irī, Abū Bakar Aysār, al-Tafāsīr li Kalām al-'Aliy al-Kabīr, Juz 1, t.t.p.: 2003.

Keputusan Lokakarya "Mencari Format Kriteria Awal Bulan Hijriyah di Indonesia 2011" diadakan di Hotel USSU Bogor pada tanggal 19-21 September 2011.

Khafid, Software Mawaqit 2001

al-Khāzin, 'Alauddin 'Aliy ibn Muhammad, Tafsìr al-Khāzin al-Lubāb al-Ta'wīl fì Ma'ānī al-Tanzīl, t.t.p.: 1979.

Malik, Ibn Anas ibn, al-Mudawwanah al-Kubrā, juz 1, Beirut: Dār al-Kutub al'Ilmiyyah, t.th.

Malik, Ibn Anas ibn, al-Muwatța', t.t.p.: Mawqi' Wizārāt al-Awqaf al-Miṣriyyah, t.th.

Moore, Sir Patrick (ed.), Philip's Astronomy Encyclopedia, London: Philip's Group, 2002.

Moulton, Forest Ray, An Introduction to Astronomy, New York: The Mac Millan Company, 1916.

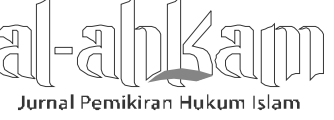


Nur Aris

Muslim, Abū al-Husayn ibnu al-Hajjāj, al-Jāmi' al-Ṣaḥịh, Beirut: Dār al-Jayl, t.th.

al-Nasā'ī, Abu Abd al-Raḥman, Sunan al-Nasā'î, Mawqi' Wizārāt al-Awqāf alMișriyyah: t.t.p., t.th.

al-Nawāwī, Abū Zakariyya Yahyā ibn Sharaf, al-Majmū' Sharh al-Muhādhdhab, Kairo: Dār Ihyā' at-Turāth al-'Arabī, 1422.

al-Qarafi, Șihābuddin Ahmad ibn Idris, adh-Dhākirah, juz 2, Beirut: Dār al-Gharb, 1994.

Qa'lahjī, Muhammad Rowas, Mu'jam Lughāt al-Fuqahā', Beirut: Dār an-Nafāis, 1988.

Richards, E.G., Mapping Time: the Calendar and Its History, New York: Oxford University Press, 199.

Ridpath, Ian, Oxford Dictionary of Astronomy, New York: Oxford University Press, 1997.

Shākir, Aḥmad Muhammad, 'Awā'il al-Shuhūr al-'Arabiyyah Hal Yajūzu Shar'an Ithbātuhā bi 'l-Hisāb al-Falakiy, Kairo: Makabah Ibn Taymiyah, 1407.

al-Shātịī, Ibrāhim ibn Mūsā ibn Muhammad, al-Muwāfaqāt, t.t.p.: Dār Ibn 'Affān, 1997.

Tim Majelis Tarjih dan Tajdid PP Muhammdiyah, Pedoman Hisab Muhammadiyah, Yogyakarta: Majelis Tarjih dan Tajdid Muhammadiyah, 2009. 